In his summing-up, Prof. Blackett stressed four points: first, nothing we can do, short of nuclear warfare, can alter the fact that a great increase in population is inevitable in the near future; secondly, the technical 'know-how' exists; thirdly, there must be initiative and 'crash-action; fourthly, the educational aspect is vital and we should open the doors of our universities and technical colleges, however difficult it may be, more widely to overseas students. Finally, he felt that the day's useful discussions had ended on a note of restrained but robust optimism.
L. Dudley Stamp

\title{
AFFORESTATION OF INDUSTRIAL WASTE
}

$\mathrm{T}$ HE sight of derelict land is all too familiar in the industrial areas of Great Britain, and the purpose of the session which was held in Sub-section $\mathrm{K}^{*}$ (Forestry) of the British Association on September 2 in Cardiff was to explore the possibilities of afforestation as a land-use tool to improve the amenities of such areas. The three speakers looked at the problem from different points of view : that of a Forestry Commission officer, a planning officer of a county council, and a land agent to an owner of substantiall areas of ironstone workings. It was refreshing to find that there was a large measure of agreement between all three as to where and in what circumstances afforestation could be usefully employed.

The symposium was opened by J. Q. Williamson of the Forestry Commission with a review of the evidence which has been built up over the past fifty years on the planting of trees on colliery spoil heaps. In his opinion the earlier doubts as to the success of such planting because of the probable lack of fertility of such apparently sterile sites has proved groundless. A large range of tree species can be planted successfully on tips so long as certain precautions are observed. The choice of planting species must first be governed by local conditions, particularly by the smoke pollution factor, which may rule out all conifers. Exposure is of great importance in tree growth generally, and the miniature mountains created by many spoil heaps could lead to severe exposure, especially if the heap happened to be already in an exposed position.

In areas where there is atmospheric pollution, birch, alder, sycamore, and in more fertile sheltered areas, ash and poplar, were recommended by $\mathrm{Mr}$. Williamson as the most likely to succeed. Where tips are situated in more rural areas, over which the atmosphere is purer, conifers can also be grown, and this is much more attractive from the economic point of view. Of the conifers, Corsican and Austrian pine are usually to be preferred, but Japanese larch and Scots pine can also do well. His experience has shown that there is no special difficulty in establishing such species by normal forestry methods, but the trees must be looked after. Grazing animals must be rigorously excluded from the young plantations and, most important of all, the local population must be taught to cherish the young trees. Most failures in the past have been due to vandalism, and it is almost a waste of time to embark on a planting scheme unless there is a determined effort to guard the trees from damage during their early years. He recommended. strongly that a programme of forestry education for the local population should accompany the planting of any colliery spoil heap, and if possible the local school children should be encouraged to take part in the actual planting and to look on the resulting woods as their own.
Mr. Williamson then gave details of the experimental afforestation of an open-cast coal site in Coed Morgannwg. He pointed out that by applying a restoration specification, which did not entail levelling and restoration of the top soil, a great deal of money can be saved. The result of this work had been most encouraging, and of the species used Corsican pine, Lawson cypress and Japanese larch among the conifers and common alder, grey alder and false acacia among the hardwoods had grown well. The trees on the more porous slopes had grown better than on the level ground where the passage of heavy machines had led to compaction of the soil.

After this technical appraisal of the problem, it was encouraging to learn from Mr. J. Casson, of the Planning Department of the Lancashire County Council, that the extensive work of afforestation carried out by his Department over the past nine years has led him to the same conclusions. $\mathrm{He}$ considers that there are thousands of acres in Lancashire alone which could be afforested with comparative ease and at not much, if any, greater expense than that incurred in establishing forest crops on normal sites. It is unfortunate that not many planning authorities in England and Wales have yet made use of Section 89 of the National Parks and Access to the Countryside Act of 1949 to undertake planting work aimed at enhancing the countryside. $\mathrm{He}$ considers that while the main objective of such a planting programme is the improvement of amenities, this work could obviously, to a greater or lesser degrea, make a contribution to the economy of any area where forestry operations could be successfully carried out. The effect of enhanced amenities in checking emigration and attracting new industry could well be valuable in arresting economic decline; the converse is undoubtedly true-ugliness leads to emigration and discourages new industrial development. He looked on the work done in Lancashire up to the present as being mainly a fact-finding exercise to see how far forestry operations are practicable under various conditions of difficulty (climate, soil, pollution, etc.). They have located their siting in significant localities as experiments, not only in forestry, but also in the use of forestry as an instrument of land-use policy in the overall physical and economic rehabilitation of depressed and damaged regions. His Council's policy has been to acquire or plant under agreement without resort to compulsory purchase. While there is a wide choice of sites which might be planted in Lancashire, it is significant that land acquisition rather than technical difficulties has been the greatest problem in planning a forward programme. For every 100 acres planted, investigations and negotiations have been opened for 200-300 acres which have had to be 
abandoned for one reason or another. Shifts in the value of waste materials and land, the presence of 'admitted' claims, conflict in the opencast coal. mining programmes, changes in legislation affecting land values and acquisition procedures, and the psychological factor that as soon as a public authority takes an interest in dereliet land its 'value' often rises sharply, have all helped to hinder progress. In spite of this, he thought that it would not be justifiable to use the compulsory powers of the Act in the absence of any overall plan for rural afforestation and with such a wide choice of sites. The same arguments would not be so applicable in urban areas where town plans are well advanced.

More than 300 acres has been planted in Lancashiro since 1951 under this scheme, and a great variety of sites has been tackled, varying from colliery spoil heaps, hæmatite waste and Gritstone quarries to degenerato woodland and bare land and moorland. The excellent slides shown by Mr. Casson and his forester assistant, Mr. L. A. King, illustrated very well the progress of the work and, although they had had their failures, it was obvious that, taken as a whole, this well-thought-out planting scheme has been most successful. Fourticen men are now employed on the work and a small nursery has been established to provide the necessary plants. With the development of 'know-how', they are increasingly able to introduce an element of landscape design into the work and they feel that they are now more successfully harmonizing economic, ecological and amenity aspects within a 'forestry' approach.

In spite of the very encouraging picture that was emerging, Mr. Casson admitted that there is a great deal still to be learned, and he made a strong plea that more scientific research should be done on the biological and technical problems posed by land dereliction, mineral working and the tipping of waste. He thought that such work would be of value not only to programmes of reclamation but also in the greater and increasing field of the planning control of the extractive industries. He realized that it is asking a great deal of local authorities to expect that they should embark on forestry schomes without the technical skills or documented data necessary to bring about a transformation in their derelict areas by using forestry; nevertheless, a great deal more could be done than was being done at present.

It was perhaps appropriate that Mr. Casson's inspiring talk on the tremendous possibilities of extending afforestation on industrial waste should be followed by a very factual account of the successful afforestation of ironstone workings in Northamptonshire on a really large scale. Mr. J. W. Houldsworth, land agent for the owners, Stewarts and Lloyds Minerals, Ltd., quoted chapter and verse of how more than 1,000 acres of land left derelict on 'hill and dale' after the ironstone had been extracted is now carrying flourishing plantations. This woodland area provides considerable amenity value to the nearby industrial town of Corby, as some of the earlier plantations are now 25-30 years of age and looking most attractive. Experience has shown that on the lighter soils a mixture of 40 per cent Furopean larch with 40 per cent sycamore and 20 per cent Scots or Corsican pine is most suitable for the site, and the present intention is to leave the sycamore as a final crop after the gradual removal of the conifers. On the heavior boulder clay, common alder and oceasion- ally oak have been planted, but this latter species has been very slow growing.

A permanent staff of 20 men is maintained under a head forester and two foremen. 'The biggest problem facing the Company is not the establishment of plantations but the extraction of produce from then, espocially as the size of pole increases as the plantations mature. Up to date there has been no difficulty in disposing of the produce, because a small estate sawmill is maintained for converting it into fencing material for use on the estate and quarries; a large quantity of the second-grade material goes into the steel work for loading strips.

Mr. J. W. Houldsworth was emphatic that, apart from the difficulty of extraction, the establishment and maintenance of plantations on this very unprom ising waste present no particular problems ; in fact there are certain advantages over normal forestry, as no weeding or cleaning is necessary on these bare 'soils'. His conclusion was that afforestation is the most economic solution to the problem of treating some of this worked ironstone land, and that it would prove a good long-term investment.

In the discussion which followed the papers, it was generally agreed that much more use could be made of afforestation in reclaiming industrial waste than had been done in the past. One of the main problems which perhaps makes public authorities a little reluctant to embark on ambitious schemes is the difficulty of making more than intelligent guesses as to what will grow successfully on any particular site. As each site usually varies so greatly within itself, the cost of extensive soil analyses is scarcely justified, and the general opinion of the meeting was that although more research should be undertaken on the constitution and plantability of the various types of industrial waste, there is now sufficient evidence to convince the most doubting authority that at least the easier sites could be planted with a fair degree of confidence.

The most controversial point discussed was the future treatment of plantations on waste land, once they were approaching maturity. Mr. Williamson thought that it would be of no use ever to consider clear felling and replanting, and advocated the introduction of some form of uneven-aged selection system in order that the soil was never bared and the amenity was maintained ; but several others felt that there was no reason why such areas should not be clear-felled on maturity and then replanted, so long as attention was paid to shelter belts being left where necessary.

On the extraction problem in the plantations on the ironstone worlsings, the simple solution of using horses was suggested for at lcast the small- and mediumsized produce.

The growth of different species was discussed, sycamore and birch in particular, and it was agreed that both these species are difficult to establish; this accords with normal field experience.

This symposium did not minimize the difficulties which are present in the planting of industrial waste, where every site and every part of a site has to be considered separately; but thore seems to be no doubt that enough knowledge is now available to encourage public authorities to embark on more ambitious planting schemes than they havo ventured on up to date. The inspiring example of Lancashire will, it is hoped, lead to a moro vigorous approach being made to this problem in many other parts of Britain.
J. Q. WILLIAMSON 